\begin{tabular}{|c|c|c|}
\hline $\begin{array}{l}\text { EXCELLENT } \\
\text { PUBLISHERS }\end{array}$ & $\begin{array}{l}\text { International Journal of Current Research } \\
\text { and Academic Review } \\
\text { ISSN: 2347-3215 (Online):,; Volume } 5 \text { :,; Number } 10 \text { (October-2017) } \\
\text { Journal homepage: http://www.ijcrar.com }\end{array}$ & 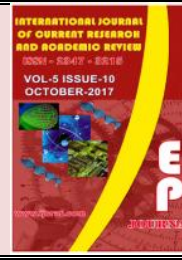 \\
\hline
\end{tabular}

doi: https://doi.org/10.20546/ijcrar.2017.510.003

\title{
Characteristics of Raw Wastewater from Albanian Dairy Processing Plants and Some Treatment Options
}

\author{
Ilirjana Boci ${ }^{{ }^{*}}$, Xhuljeta Hamiti ${ }^{1}$ and Ariela Struga ${ }^{2}$ \\ ${ }^{I}$ Department of Industrial Chemistry, Faculty of Natural Sciences, University of Tirana, Albania \\ ${ }^{2}$ Albanian University, Albania \\ *Corresponding author
}

\section{Abstract}

The dairy industry has undergone an increasing pressure to improve its environmental performance because of wastewater discharges characterized by high chemical oxygen demand, biological oxygen demand, nutrients, organic and inorganic matter. The pressures for change have resulted from ongoing changes in environmental legislation. The government of Albania has started to impose very strict rules and regulations for the effluent discharge to protect the environment. This paper presents the data obtained from the physical chemical analysis performed in wastewater effluents generated from dairy processing plants in Albania. Analysis of raw and pretreated wastewater have been carried out. Frequent wastewater samplings have been made according to peak plant production. The composite samplings have been made to the effluent flow before mixture with the stream water body. We collected 12 samples from a big dairy plant (with continuous production process) that discharges wastewaters into a water stream flowing into the Adriatic Sea shore. The samples were analyzed for $\mathrm{pH}$, conductivity, $\mathrm{COD}, \mathrm{BOD}_{5}$, suspended solid content, organic nitrogen, phosphorus as orthophosphate and chloride. Analyses were done according to methods outlined in Metodi Analitici per le Acque (APAT).The analytical data obtained even after preliminary treatment were still higher than Albanian Standards permissive norms respectively $3800(\mathrm{mg} / \mathrm{L})$, $7700(\mathrm{mg} / \mathrm{L}), 2850(\mathrm{mg} / \mathrm{L}), 90(\mathrm{mg} / \mathrm{L}), 28(\mathrm{mg} / \mathrm{L}), 70 \mathrm{mg} / \mathrm{l}$. It is necessary for dairy companies to be forced by legal or economic pressures to reduce the amount and concentration of pollutants in their effluent streams. The problem is more serious for the companies that discharge their wastewater directly into rivers, which is the case for some dairy plants located in the northern region of Albania. Basing on the results we recommend that dairy industry should seek other options to improve environmental performance. Some proper alternatives are mentioned and recommended in this paper as well.
\end{abstract}

\section{Article Info}

Accepted: 04 September 2017

Available Online: 20 October 2017

\section{Keywords}

Dairy processing plant,

Wastewater,

Effluent,

Characteristics,

Effect.

\section{Introduction}

In Albania, nowadays milk processing activities are widespread all over the country mostly near the seaside places. Plant expansions have contributed to a marked increase of dairy processing factories. The increase in milk production has lead that processing sites must run harder and longer, particularly during seasonal peaks. 
The milk industry generates a wastewater volume at 1 to 3 times higher than milk processed (11) Waste water is generated in milk processing unit, mostly in pasteurization, homogenization of fluid milk and the production of dairy products such as butter, cheese, milk powder etc. Most of the milk processing unit use cleaning solutions through all equipment in this order water rinse; caustic solution (sodium hydroxide) wash, water rinse, acid solution (phosphoric or Nitric acid) wash, water rinse, and sodium hypo-chlorite disinfectant. These chemicals eventually become a part of waste water (11) Large amount of water is used to clean dairy processing plants; hence, the resulting waste water can contain detergent, sanitizers, base, salts and organic matter, depending upon source.

Dairy processing effluent contains predominantly milk and milk products leached from the process, as well as detergents or acidic and caustic cleaning agents (1). The constituents present in dairy effluent are milk fat, protein, lactose and lactic acid, as well as sodium, potassium, calcium and chloride. Milk loss to the effluent stream can amount to $0.5-2.5 \%$ of the incoming milk, but can be as high as 3-4\% (2).

Many surveys have found that effluent loads from dairy processing plants depend, to some extent, on the type of product being produced (3). The scale of the operation and whether a plant uses batch or continuous processes also have a major influence, particularly for cleaning step. This is because small batch processes requires more frequent cleaning. The tendency within the industry towards larger plants is thus favorable in terms of pollutant loading per unit of production.

Dairy factories are facing the problem of water treatment, disposal and utilization of the waste water. Disposal of waste water into rivers, land, fields and other aquatic bodies, without or with partial treatment, in sedimentation tanks or just aseptic tank, will soon offer a serious problem to health and hygiene. In frame of the Best Practice Environmental Management Guidelines (4) developed in many countries in conjunction with the dairy processing industry we would like to be useful to help the industry address its environmental obligations more effectively.

The target of this study is to build a database with the characteristics of food industry wastewaters in Albania in general and of the dairy plants in particular as having the most potential negative impact in waters body because mainly of the water quantity used, followed then with data collected from other agro food industries, such as meat, vegetable $\&$ fruit and oil processing. This database will be helpful to know exactly the environmental impact share from food processing sector that use the seaside shore or surface water body as a sink to discharge their wastewaters. Our study is focused on one of the main milk processing plants in our country in Kavaja city, located in the central region of Albania, near the seaside. The wastewater from the main plant outlet is discharged to a water stream following next into the sea. This plant consumes approx. 31 water $/ \mathrm{kg}$ product, which is high taking into consider the large production rate. The sampling was done during March - June 2016 period in order to know and make an overall estimation of the characteristics of milk processing wastewater in order to assess the potential pollution to the receiving surface water.

\section{Materials and Methods}

The physical and chemical parameters of the wastewater were monitored before and after the preliminary treatment at the plant which consisted of a sedimentation tank and a grease trap.

All samples were analyzed for the following parameters: $\mathrm{pH}$, conductivity, COD, $\mathrm{BOD}_{5}$, suspended solid content, organic nitrogen, phosphorus as orthophosphate, and chloride.

All the samples have been taken more or less at the peak time of plant operating hours in order to properly estimate the maximum environmental risk of wastewater produced. Sampling was made according to the detailed procedure described in literature (Metodi Analitici per le Acque) and stored at proper temperature until next day when it was not possible testing the same sampling day. Analyses were done mainly according to Metodi Analitici per le Acque (5) for BOD, COD and TSS and according to methods described fully in the text book (6) for $\mathrm{pH}, \mathrm{E}_{\mathrm{red} / \mathrm{ox}}$, organic nitrogen, phosphate content; biochemical oxygen demand-BOD was obtained by determining the dissolved oxygen content in water after sampling and after 5 days, and the difference is referred as BOD5; chemical oxygen demand-COD was determined by potassium dichromate titrimetric method; total solid suspensions were determined by filtration in $0.45 \mu$ membrane filter, $\mathrm{pH}$ using a $\mathrm{pH}$ meter; proteinic nitrogen was determined with Kjeldahl method; inorganic phosphorus was determined using ammonium molybdate spectrometric method and chloride by titrimetric method by silver nitrate. 


\section{Results and Discussion}

\section{pH}

$\mathrm{pH}$ is one of the important biotic factors that serves as an index for pollution. The $\mathrm{pH}$ value of raw waste water varied from 6.7-7.9. The $\mathrm{pH}$ of waste water indicated the acidic nature of effluent during investigation. Slight acidic nature of waste water was due to break down of milk lactose in to lactic acid.

\section{Electric conductivity}

Electrical Conductivity values were varying from 1735 $2480 \mu \mathrm{s} / \mathrm{cm}$ in raw waste water.

\section{TS}

Total solid values were varying from 6450-7670 ppm in raw waste water.

\section{Chloride}

Chloride values ranged from $35-120 \mathrm{mg} / \mathrm{L}$ in raw waste water.

\section{Biochemical Oxygen Demand}

B.O.D. is defined as the amount of oxygen required by microorganism while stabilizing biological decomposable organic matter in waster aerobic conditions. The biological oxidation is a very slow process during oxidation organic pollutants are oxidized by certain microorganism into carbon dioxide and water using to dissolve oxygen. Hence lowering in dissolved oxygen value is the measure of BOD relation (11).

Biological oxygen demand is an important parameter that indicates the magnitude of water pollution, by the oxidizable organic matter and the oxygen used to oxidize inorganic materials such as sulphides and ferrous ions.

In natural source, the oxidizable matter on oxidation enters into the biogeochemical cycle BOD does not work independently hence it performs to well depend on so many called factors; low value of BOD in comparatively wider months may be due to lesser quantity of total solids, dissolved solids, suspended solids in water as well as to the quantitative number microbial pollution. In the present study BOD of raw wastewater was $4500 \mathrm{mg} / \mathrm{l}$ observed.

\section{Chemical Oxygen Demand}

The COD is a test, which is used to measure pollution of domestic and industrial waste. The waste is measured in terms of quality of oxygen required for oxidation of organic matter to produce carbon dioxide and water. It is a fact all organic compounds with few exceptions can be oxidized by the action of strong oxidizing agents under acidic conditions COD is a useful test for assessment of presence of biological resistance substances. The ratio of the BOD and COD can provide more information on the wastewater sample. Usually, for industrial wastewaters, COD is higher than BOD because many organic substances, which are difficult to oxidize biologically can be oxidized chemically. If the COD value is much bigger than the BOD value, the organic compounds in wastewater are slowly biodegradable. The conjugation of BOD test, with COD test is helpful in indication of toxic conditions and the presence of biological resistance. (11) The chemical oxygen demand values were $7900 \mathrm{mg} / \mathrm{L}$ for the raw waste water.

\section{Total ortho phosphate}

Total ortho phosphate values were varying from 25-37 $\mathrm{mg} / \mathrm{L}$ in raw waste water. Higher and lower value of ortho phosphate was dependent on the amount of discharge and the temperature suitability for breakdown.

\section{Organic nitrogen}

Organic nitrogen value determined in $\mathrm{mg} / \mathrm{L}$ was ranging from 85-140 in raw waste water of milk processing unit.

The average value of the analytical data obtained for $\mathrm{pH}$, conductivity, $\mathrm{BOD}_{5}, \mathrm{COD}$, Total Suspended Solids, Norganic, Total P (as orthophosphate) and chloride of the raw wastewater were respectively: $6.7,2100(\mu \mathrm{S} / \mathrm{cm})$, 4050 (mg/L), 7900 (mg/L), 7100 (mg/L), 110 (mg/L), 32 (mg/L), $75 \mathrm{mg} / \mathrm{l}$.

These results show that wastewater is characterized relatively by high organic load, nitrogen and phosphorus. The values of the most of the parameters obtained from the samples after the preliminary treatment applied by the dairy factory seems to be slightly decreased but they still remain higher than the Albanian Standards permissive norms (7).

In the figure 1 below are presented the mean values of the wastewater quality indicators monitored: BOD, COD. 
Table.1 Value of the physic chemical parameters of the wastewater samples

\begin{tabular}{|l|l|l|l|l|l|l|l|l|}
\hline Indicators & $\mathrm{pH}$ & $\begin{array}{l}\text { Conductivity } \\
(\mu \mathrm{S} / \mathrm{cm})\end{array}$ & $\begin{array}{l}\mathrm{TSS} \\
(\mathrm{mg} / \mathrm{l})\end{array}$ & $\begin{array}{l}\mathrm{BOD} \\
(\mathrm{mg} / \mathrm{l})\end{array}$ & $\mathrm{COD}(\mathrm{mg} / \mathrm{l})$ & $\begin{array}{l}\mathrm{N}_{\text {total }} \\
(\mathrm{mg} / \mathrm{l})\end{array}$ & $\begin{array}{l}\mathrm{P}_{\text {total }} \\
(\mathrm{mg} / \mathrm{l})\end{array}$ & $\begin{array}{l}\text { Cloride } \\
(\mathrm{mg} / \mathrm{l})\end{array}$ \\
\hline Mean before treatment & 7.5 & 2100 & 7100 & 4050 & 7900 & 110 & 32 & 75 \\
\hline $\begin{array}{l}\text { Mean after preliminary } \\
\text { treatment }\end{array}$ & 6.6 & 1840 & 2850 & 3900 & 7200 & 90 & 28 & 69 \\
\hline Albanian norms & $6-9$ & - & 50 & 50 & 250 & 10 & 2 & \\
\hline
\end{tabular}

Fig.1 Values of BOD and COD in wastewater samples before and after preliminary treatment

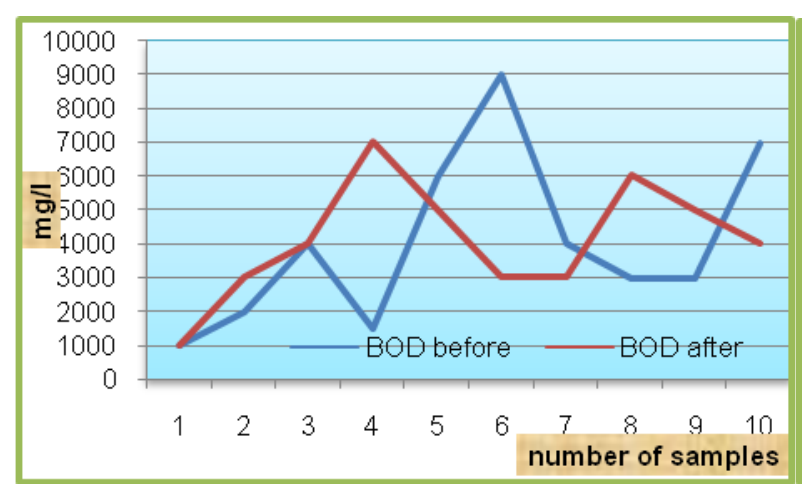

The results presented in the figure 1 show that raw wastewaters from dairies plant contain high biological oxygen demand (BOD) and chemical oxygen demand (COD) with the mean values 4050 (mg/l) and 7900 (mg/l) respectively. It seems obviously the BOD and COD values after the preliminary treatment of the factory still remain relatively high with the mean value $3900(\mathrm{mg} / \mathrm{l})$ and $7200(\mathrm{mg} / \mathrm{l})$. In the table 1 we notice that preliminary treatment has decreased the $\mathrm{pH}$ values from 7.5 till 6.6 and has a positive impact to reduce suspended solid content approximately at $60 \%$. Anyway it is important to note that the fluctuation of the BOD and COD values during the sampling period is very high, approximately up to twice the average value, making the pollution problem much more serious in the peak time.

The data presented in the table show that the dairy wastewaters contain high levels of nitrogen and phosphorus concentrations and their values are still higher even after the preliminary aseptic treatment, higher than the permissive norms outlined from the Decision of the Council of Ministers Nr.177 dated on 31.03.2005.(7)

\section{Wastewater treatment and disposal options for milk industry}

The considerable values of the above presented pollutants in food industry in general and milk industry

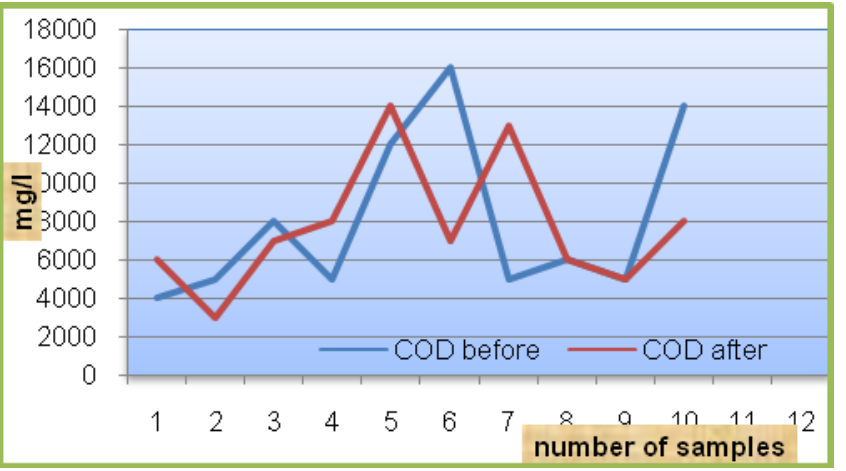

in particular have drawn attention to find the proper solutions to decrease mainly the quantity generated because their biodegradable and non-toxic nature makes them fit for simple and non-expensive treatment options generally.

Because of the highly seasonal nature of milk production, during peak periods the volume of wastewater generated at dairy plants may be several times greater than during off peak periods.

The batch nature of many processes, and intermittent operations such as cleaning and sanitizing, also means a wide daily variation in wastewater flows and quality.

The first and the most recommended option for dairy factory wastewater relates to source reduction on site to a suitable standard for reuse or recycling. Reuse and recycling can considerably decrease the volume of mains water required to operate the plant and also reduce the cost of both process water and wastewater disposal. Many dairy plants all in developed and in developing countries implement technologies for recovering wastewater. Unfortunately this is not the case for Albania. Whenever source reduction or reuse is fully implemented discharge to local sewers after pretreatment as necessary is the widely used option. Even if there is the case for wastewater treatment, the volume and organic load of wastewater from just one dairy 
factory during peak season may interfere and have an impact on domestic waste quantity and quality as well. This may overload the sewage treatment plant, cause odors and give rise to poor effluent quality.

Dissolved salts contained in dairy plant wastewater can adversely affect soil structure if wastewater is used to irrigate land. Wastewater can also leach into underlying groundwater and affect its quality especially if high level of chloride is present which is the case for some food industries. Over-irrigation may cause the underlying water table to rise, resulting in further deterioration of surface soils and vegetation. (12)

Dairy wastewater effluents are usually highly variable, with quantity and quality variations brought about by batch discharges, operation start-ups and shutdowns, working-hour distribution and so on. From physicochemical studied of dairy waste it was concluded that waste water discharged from milk processing unit show high turbidity because of high suspended solid matter. Salinity is high as well as electrical conductivity and total dissolved solids. The wastewaters from the dairy processing industry in Albania seems to contain also a high concentrations of organic material such, high biological oxygen demand (BOD) and chemical oxygen demand (COD) even after preliminary treatment performed on site. A long-term detailed survey is usually necessary before a conclusion on the pollution impact from this sort of industry can be drawn. With the exception of some toxic cleaning products, wastewater from food-processing industry is highly organic and can be treated by conventional biological technologies. Higher quantity of inorganic nutrients like nitrogen \& phosphorus was found present in the waste water Nitrogen and phosphorus removal can be achieved through special wastewater purification systems, which are based on either biological or physic-chemical processes. Its disposal without any treatment in to fresh water body may impose the danger of eutrophication as well as serious problems of health and hygiene.

There are so many investigations from a numerous studies to find solution for cheaper treatment, easy disposal and utilization of waste water from milk processing unit. Dairy factory sludge characterized by low heavy metal content and high amounts of degradable carbon can prevent the depletion of soil nutrients caused from intensive harvesting. Anaerobic treatment of dairy waste water treatment for biogas production in anaerobic batch reactor is another mean for optional treatment dairy industry sludge. Use as a fertilizer for an acid soil is already investigated by different authors $(8,11$, 12).The utilization of dairy waste effluent provides nutrients and water for crop growth is also studied. 5\% dairy waste solids in feeding diet of sheep and swine is an alternative means for combating solid disposal problem of dairy industry $(11,12)$.

\section{Acknowledgment}

The authors express their gratitude to the managers and the staff of the dairy processing plants in Albania who gave their assistance for sampling, as well as for their willingness and interest to discuss for collaboration in the future for their wastewater treatment options.

\section{References}

1. Kolhe, A.S., S. R. Ingale, Dr. R. V. Bhole (Nov-Jan 2009), Effluent of Dairy Technology Shodh, Samikshaaur Mulyankan (International Research Journal), Vol. II, Issue-5

2. Oneţ Cristian (2010), Characteristics of the untreated wastewater produced by food industry Analele Universităţii din Oradea, Vol. XV. Pp. 709714.

3. Mrs. Bharati S. Shete, Dr. N. P. Shinkar1. Comparative Study of Various Treatments for Dairy Industry Wastewater. IOSR Journal of Engineering (IOSRJEN) Vol. 3, Issue 8 (2013), 42-47.

4. Environmental, Health, and Safety Guidelines for Dairy Processing. www.ifc.org/ifcext/enviro.nsf/ Content/Environmental

5. Metodi Analitici per le Acque (APAT). Metodianal itici per le acque. Metodi Campionamento Manuali e Linee Guida 29 (2003).

6. Cullhaj A. Kimia e mjedisit- Universiteti i Tiranes, Fakulteti i Shkencave te Natyres (2010).

7. Vendim, Nr.177, datë 31.3.2005 "Përnormat e lejuaratësh karkimevetëlengët adhekriteret e zonimit tëmjedis eveujorepritëse").

8. Campos, J.R., Foresti E. and Camacho R.D.P., 1986, Anaerobic treatment in the food processing industry: Two case studies, Water Science Technology. Pp. 87-97.

9. Oneţ C., Oneţ Aurelia, 2011, Dynamics of water usage in food industry according to technological process, Analele Universităţi din Oradea, Fascicula Protectia Mediului, vol. XVI, Anul 16, Editura Universităţii din Oradea.

10. Oneţ C., Oneţ Aurelia, 2011, Management of the wastewater discharged by the milk and meat processing factories, Analele Universităţi din 
Oradea, Fascicula Protecţia Mediului, vol. XVI, Anul 16, Editura Universităţii din Oradea.

11. Ashish Tikariha, Omprakash Sahu, Study of

Characteristics and Treatments of Dairy Industry

Waste Water, 2014, pp 4-6.

\section{How to cite this article:}

Ilirjana Boci, Xhuljeta Hamiti and Ariela Struga. 2017. Characteristics of Raw Wastewater from Albanian Dairy Processing Plants and Some Treatment Options. Int.J.Curr.Res.Aca.Rev. 5(10), 15-20.

doi: $\underline{\text { https://doi.org/10.20546/ijcrar.2017.510.003 }}$
12. Environmental Guidelines for the Dairy Processing Industry, pp 15-16. 